\title{
MUC4 mucin expression in human pancreatic tumours is affected by organ environment: the possible role of TGF $\beta 2$
}

\author{
A Choudhury ${ }^{1,5}$, N Moniaux ${ }^{1,5}$, AB Ulrich², BM Schmied ${ }^{2}$, J Standop'2, PM Pour ${ }^{2}$, SJ Gendler ${ }^{3}$, \\ MA Hollingsworth ${ }^{2}$, J-P Aubert ${ }^{4}$ and SK Batra ${ }^{*, 1,2}$
}

'Department of Biochemistry and Molecular Biology, University of Nebraska Medical Center, Omaha, NE, USA; ${ }^{2}$ Eppley Institute for Research in Cancer and Allied Diseases, University of Nebraska Medical Center, Omaha, NE, USA; ${ }^{3}$ Mayo Clinic Scottsdale, Scottsdale, AZ, USA; ${ }^{4}$ Unite 560 INSERM, Place de verdun, Lille Cedex 59045, France

\begin{abstract}
MUC4 is highly expressed in human pancreatic tumours and pancreatic tumour cell lines, but is minimally or not expressed in normal pancreas or chronic pancreatitis. Here, we investigated the aberrant regulation of MUC4 expression in vivo using clonal human pancreatic tumour cells (CDI8/HPAF) grown either orthotopically in the pancreas (OT) or ectopically in subcutaneous tissue (SC) in the nude mice. Histological examination of the OT and SC tumours showed moderately differentiated and anaplastic morphology, respectively. The OT tumour cells showed metastases to distant lymph nodes and faster tumour growth $(P<0.0 \mathrm{I})$ compared to the SC tumours. The MUC4 transcripts in OT tumours were very high compared to the undetectable levels in SC tumours. The SC tumour cells regained their ability to express MUC4 transcripts after in vitro culture. Immunohistochemical analysis using MUC4specific polyclonal antiserum confirmed the results obtained by Northern blot analysis. Interestingly, the OT tumours showed expression of TGF $\beta 2$ compared to no expression in SC, suggesting a possible link between MUC4 and TGF $\beta 2$. The MUC4 expression, morphology, and metastasis of human pancreatic tumour cells are regulated by a local host microenvironment. TGF $\beta 2$ may serve as an interim regulator of this function.

British Journal of Cancer (2004) 90, 657-664. doi:I0.1038/sj.bjc.660I604 www.bjcancer.com

(C) 2004 Cancer Research UK
\end{abstract}

Keywords: pancreatic adenocarcinoma; mucin; MUC4; orthotopic environment; TGF $\beta 2$

Pancreatic adenocarcinomas are frequently associated with an altered synthesis of mucins (Balague et al, 1994; Hollingsworth et al, 1994; Kim et al, 1999; Andrianifahanana et al, 2001). Biochemically, mucins are high-molecular-weight glycoproteins and their polypeptide chains have domains rich in threonine and/ or serine, whose hydroxyl groups are in $O$-glycosidic linkage with oligosaccharides. These domains are composed of tandemly repeated sequences that vary in number, length, and amino-acid sequence from one mucin to another (Gendler and Spicer, 1995; Moniaux et al, 2001). They are produced mainly by the secretory epithelial cells for the lubrication and protection of ducts and lumen within the human body (Gendler and Spicer, 1995). In all, 14 human mucin genes have been identified, designated as MUC14, MUC5B, MUC5AC, MUC6-8, MUC11-12, MUC13, and MUC16-17 (Gendler et al, 1990; Lan et al, 1990; Aubert et al, 1991; Porchet et al, 1991; Bobek et al, 1993; Dufosse et al, 1993; Gum et al, 1994,

\footnotetext{
* Correspondence: Dr SK Batra, Department of Biochemistry and Molecular Biology, Eppley Institute for Research in Cancer and Allied Diseases, University of Nebraska Medical Center, 984525 Nebraska Medical Center, Omaha, NE 68198-4525, USA;

E-mail: sbatra@unmc.edu

This work was supported by a grant from the National Institutes of Health ROI CA 78590

${ }^{5}$ Contributed equally to this work

Received 19 August 2003; revised 12 November 2003; accepted 27
} November 2003
1997; Shankar et al, 1997; Toribara et al, 1997; Williams et al, 1999, 2001; Yin and Lloyd, 2001; Gum Jr et al, 2002). Based on the structure, mucins are categorised into three distinct forms: membrane spanning (MUC1, MUC3, MUC4, MUC12 and MUC17), gel forming (MUC2, MUC5AC, MUC5B and MUC6), and soluble (MUC7) (Moniaux et al, 2001). MUC4 has been cloned from the human trachea and human pancreatic tumours, and the full-length cDNA sequence is known (Nollet et al, 1998; Moniaux et al, 1999; Choudhury et al, 2000a). The $\mathrm{NH}_{2}$-terminus of MUC4 is composed of a 27-residue signal peptide and a large domain varying in length from 3285-7285 amino-acid residues as a result of variable number of 16 amino-acid tandem repeat units (VNTR). The COOH-terminus of MUC4 encodes 12 distinct domains that include two cysteine-rich domains, three epidermal growth factor (EGF)-like domains, two regions rich in potential N-glycosylation sites, one hydrophobic transmembrane region, and one short cytoplasmic tail. Nine out of 12 of the C-terminal domains share $60-80 \%$ similarity in sequence with the rat sialomucin complex, known as SMC. Sialomucin complex is the rat homologue of human MUC4 and is now known as rat Muc4 (Moniaux et al, 1999).

The apomucins MUC1, MUC5B, MUC5AC, and MUC6 are expressed in the normal pancreas; $M U C 1, M U C 2$, and MUC4 are upregulated in pancreatic tumours (Andrianifahanana et al, 2001), whereas MUC5B, MUC5AC, and MUC6 are slightly downregulated. The MUC4 mucin is expressed at high levels in human pancreatic tumours and tumour cell lines, with an undetectable level in the normal pancreas (Andrianifahanana et al, 2001). MUC4 is also 
658

expressed by metaplastic ducts and its expression increases with higher grade in pancreatic intraepithelial neoplasias (PanINs) (Swart et al, 2002). The human tissues showing an undetectable level of MUC4 expression are the gall bladder biliary epithelial cells, intrahepatic bile ducts, and the liver (Vandenhaute et al, 1997). In contrast, the MUC4 apomucin is expressed in numerous normal human tissues like the stomach, ovary, salivary gland, colon, lung, trachea, uterus, and prostate (Audie et al, 1993; Reid and Harris, 1998; Buisine et al, 1999; Gipson et al, 1999). During foetal development, there is a complex spatiotemporal regulation of the MUC4 gene in the gastroduodenal tract and accessory digestive glands.

The membrane-associated mucins rat Muc4 and MUC1 have been reported to play a role in tumour progression and metastasis (Gendler and Spicer, 1995; Komatsu et al, 1997, 2000; Kim et al, 1999). The implantation of human tumour cells in the pancreas of nude mice (orthotopic (OT) implantation) has proved to be useful in studying the progression of pancreatic cancer in vivo (Marincola et al, 1989). The organ microenvironment has been shown to influence the physiological properties of the tumour cells in the production of degradative enzymes and the regulation of $m d r 1$ mRNA and P-glycoprotein expression (Fidler et al, 1994). The survival and growth of a particular tumour cell are significantly affected by the local milieu provided by a particular organ environment (Fidler et al, 1994).

In the present study, the influence of the local host microenvironment on the expression of the MUC4 transcript and protein was examined for the first time. Using human pancreatic adenocarcinoma cell lines, CD18/HPAF and SW1990, human pancreatic tumour xenografts were developed at the OT and subcutaneous (SC) sites of the nude mouse. The morphologically differentiated invasive OT tumours demonstrated a high level of expression of MUC4 mRNA and protein compared to undetectable levels in poorly differentiated SC tumours. However, the in vitro culture of SC tumour cells resulted in the expression of MUC4 transcripts comparable with its expression level in the parental cell line CD18/HPAF. Paracrine stimulation by growth factors and cytokines has been demonstrated to be one of the mechanisms responsible for the organ preference and proliferation of the tumour cells. The MUC4-expressing OT tumours also showed transforming growth factor $(T G F) \beta 2$ expression. The study suggests that the site of pancreatic tumour growth in vivo strongly influences MUC4 and TGF $\beta 2$ expression, tumour morphology, and invasiveness of CD18/HPAF cells.

\section{MATERIALS AND METHODS}

\section{Animals}

Female athymic mice (nu/nu) (6-8 weeks) were obtained from Charles River (Wilmington, MA, USA). The mice were housed in laminar flow cabinets under specific pathogen-free conditions. The University of Nebraska Medical Center Institutional Animal Care and Use Committee approved animal protocols used in this study (IACUC \#97-069-03), which comply with the Public Health Service Policy on the Humane Care and Use of Laboratory Animals.

\section{Tumour cell line and tumour cell culture}

The CD18/HPAF cell line used in the study was originally derived from the parental heterogeneous HPAF pancreatic tumour cell line by a limiting dilution technique (Metzgar et al, 1982; Kim et al, 1989). Cells were cultured in Dulbecco's modified Eagle medium (DMEM) containing $10 \%$ foetal bovine serum (FBS) and penicillin-streptomycin $200 \mathrm{U} \mathrm{ml}^{-1}$ (Life Technologies Inc., Grand Island, NY, USA). The SW1990 cell line was established from spleen metastasis of grade II pancreatic adenocarcinoma derived from the exocrine pancreas (Kyriazis et al, 1983). Cells were culture in leibovitz's L-15 medium with $10 \%$ FBS and penicillinstreptomycin $200 \mathrm{U} \mathrm{ml}^{-1}$ (Life Technologies Inc.) at $37^{\circ} \mathrm{C}$ without $\mathrm{CO}_{2}$. For in vivo injections, cells were harvested from subconfluent cultures by treatment with $0.05 \%$ trypsin and $0.53 \mathrm{~mm}$ EDTA (trypsin-EDTA solution; Life Technologies Inc.) and resuspended in Hank's balanced salt solution (HBSS) for injection. Only singlecell suspensions with $>90 \%$ viability were used for injection.

A portion of tumour tissue, obtained 2 weeks after implantation of the CD18/HPAF cells into the pancreas or the SC tissue of the nude mice, was placed in a 10\% DMEM medium and minced finely with a scalpel. The medium containing the tissue pieces was centrifuged and the supernatant containing the floating fat tissue was removed. The tissue pellet was treated with DMEM supplemented with collagenase $\mathrm{P}\left(3.75 \mathrm{mg} \mathrm{ml}^{-1}\right.$ medium $)$ at $37^{\circ} \mathrm{C}$ for $15 \mathrm{~min}$. The digestion of the tissue was terminated by adding $10 \%$ DMEM. After washing the tissue three times in DMEM medium, tissue fragments were seeded into six-well plates and incubated at $37^{\circ} \mathrm{C}$ in a humidified atmosphere of $5 \% \mathrm{CO}_{2}$ in air. After $24 \mathrm{~h}$, tumour cells began to migrate out from the tissue pieces into the surrounding areas. The wells became subconfluent at day 5 and were trypsinised with Trypsin-EDTA solution twice for different time periods: first for $1 \mathrm{~min}$ to detach and remove the fibroblasts and second for $5 \mathrm{~min}$ to harvest the tumour cells. Cells were washed and seeded in flasks containing 10\% DMEM medium.

\section{OT and ectopic implantation of tumour cells}

Tumour cells were harvested from the culture flasks by trypsinisation in EDTA solution, and were washed by centrifugation in a serum-containing medium. After being washed twice in PBS pH 7.4 (Life Technologies Inc.), they were resuspended in the same buffer at a concentration of $10 \times 10^{6} \mathrm{cells} \mathrm{ml}^{-1}$. Mice were anaesthetised with $100-200 \mathrm{mg} \mathrm{kg}^{-1}$ ketamine and $5-16 \mathrm{mg} \mathrm{kg}^{-1}$ of xylazine. A volume of $50 \mu \mathrm{l}$ of cell suspension $\left(10 \times 10^{6}\right.$ cells ml $\left.^{-1}\right)$ was injected into different tissues like the pancreas, submandibular gland (SMG), ovary, stomach, and SC site. After the injection, the organ was returned to the correct position and the abdomen was sutured using chromic catgut. The skin was closed with metal clips, which were removed 10 days later. The SC injection was performed using $50 \mu \mathrm{l}$ of cell suspension at a site on the back between the scapulae. After implantation, mice were inspected twice a week. Tumour formation was checked twice a week in the first 2 weeks and daily thereafter. Tumour-bearing mice were killed when an intra-abdominal mass measuring $\sim 2 \mathrm{~cm}$ in diameter was palpated. To assess the tumour dissemination pattern, in each group at least four mice were kept alive until they were moribund. After sacrifice, primary tumours and the metastatic tumours were weighed, measured, and cut into small fragments. These fragments were processed for immunohistochemistry (IHC) or RNA isolation, or were kept in tissue culture medium and processed to obtain a cell line, as described in the previous section.

\section{Isolation of RNA and Northern blotting}

The total cellular RNA from the normal human pancreas, human pancreatic xenografts, and CD18/HPAF cell line was isolated by the guanidine isothiocyanate and cesium chloride $(\mathrm{CsCl})$ cushion ultracentrifugation method (Chirgwin et al, 1979). The Northern blots were performed as described previously (Choudhury et al, 2000b).

\section{Immunohistochemical examinations}

Xenographic tumour tissues were fixed in $10 \%$ buffered formalin and embedded in paraffin. Tumour sections $(5 \mu \mathrm{m})$ were assayed for MUC4 apomucin by using a modification of the previously 
described ABC immunohistochemical method (Pour et al, 1993; Batra et al, 1995). Briefly, tissue sections were deparaffinised in xylene, rehydrated in graded ethanol, and treated for $20 \mathrm{~min}$ with $0.3 \% \mathrm{H}_{2} \mathrm{O}_{2}$ /methanol to block endogenous peroxidase. The sections were blocked with normal goat serum for $1 \mathrm{~h}$, followed by incubation at $4{ }^{\circ} \mathrm{C}$ overnight with either anti-MUC4 rabbit antiserum raised against 16 amino-acid tandem repeat peptide (Ser Thr Gly Asp Thr Thr Pro Leu Pro Val Thr Asp Thr Ser Ser Val) or pre-immune rabbit serum as a negative control. The specificity of the antisera generated against the tandem-repeat peptide in staining pancreatic tumour cells was evaluated as described earlier (Choudhury et al, 2000b).

\section{Semiquantitative reverse transcription-polymerase chain reaction ( $R T-P C R)$}

Total RNA $(0.5 \mu \mathrm{g})$ from the tumour tissue or cell lines was reverse transcribed using the first-strand cDNA synthesis kit (PerkinElmer, Branchburg, NJ, USA) and oligo $\mathrm{d}(\mathrm{T})$ primers, according to the manufacturer's instructions. Oligonucleotide primers to the nontandem repeat region of MUCs $1,2,3,4,5 A C, 5 B, 6,7, T G F \beta 1$, and TGF $\beta 2$ are designed from the published sequences in the GenBank, as described earlier (Choudhury et al, 2000b). The mucin genes and TGF $\beta$ were coamplified with the same GAPDH primers. Amplifications were performed in a programmable thermal controller (PTC-100, MJ Research, Inc., Watertown, MA, USA). PCR amplification reactions were described previously (Andrianifahanana et al, 2001; Choudhury et al, 2000b). For convenience, the corrected densitometric scores for different products were categorised in three different ranges: high value $(+++)$, moderate value $(++)$, and weak value $(+)$. Each value was determined as the mean of four densitometry readings.

\section{RESULTS}

In vivo tumorigenicity and metastatic behaviour of $\mathrm{CD} 18$ / HPAF cells

CD18/HPAF cells were implanted orthotopically (OT) or ectopically (SC) in nude mice. After 7 days, at any given time point, the extent of tumour growth was higher at OT compared to SC sites. At 20 days after injection, the OT tumour volume was found to be 2.5fold higher as compared to the SC tumours, reflected in the tumour weight, as shown in Table 1. Among the six mice bearing OT tumours, two showed extensive invasion of the stomach and duodenum, and three showed regional invasion of the stomach and duodenum. Four mice from each group (OT and SC) were killed after 30 days when they became moribund, and were dissected to examine the sites of metastasis. Tumours of CD18/ HPAF cells in pancreas (OT tumours) showed a high incidence of metastases to regional lymph nodes (LNs) and distant metastasis to mediastinal LNs and mesenteric LNs. In contrast, the SC tumours were confined to the site of injection and none of the mice harbouring these tumours showed detectable signs of metastases
(Table 1). None of these tumours (OT or SC) showed any signs of necrosis.

Similar results were obtained using another pancreatic tumour cell line, SW1990, where a significant difference in tumour volume $(P<0.01)$ was observed for the OT tumour $6182+1003 \mathrm{~mm}^{3}$ compared to SC tumour $1774+844 \mathrm{~mm}^{3}$. The OT tumours

A

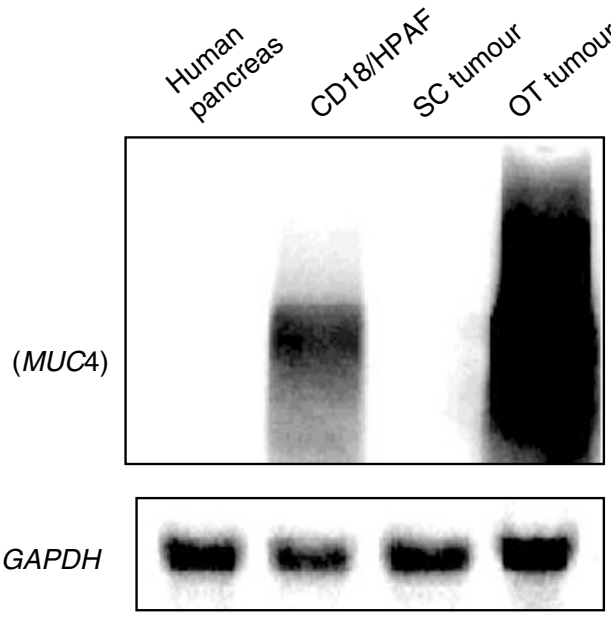

B Steady-state MUC4 mRNA levels

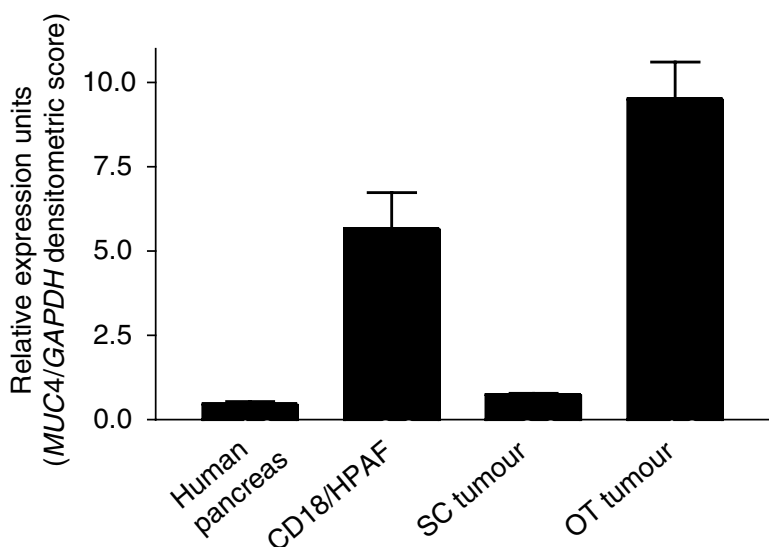

Figure I Northern blot of total cellular RNA $(20 \mu \mathrm{g})$ separated in a I\% agarose/formaldehyde gel from the normal human pancreas tissues, CDI 8/ HPAF cultured cells, and the CDI8/HPAF cells grown as SC and OT tumours. (A) Blot was probed with a ${ }^{32}$ P-labelled MUC4 tandem repeat cDNA probe, and the same membrane was stripped and hybridised with a GAPDH cDNA probe. (B) Densitometric values ( \pm s.e.) for the bands above in three different experiments were determined by using Molecular Dynamics ImageQuant software program. Values obtained for the MUC4 smear were divided by the densitometic values for the GAPDH band.

Table I Tumorigenicity and production of spontaneous metastases in CDI8/HPAF cells

\begin{tabular}{lccccc}
\hline Injection site $^{\mathbf{a}}$ & Latent period $^{\mathbf{b}}$ & Tumour volume $^{\mathbf{c}}$ & Tumour weight $^{\mathbf{d}}$ & Tumorigenicity $^{\mathbf{e}}$ & LN metastases $^{\mathbf{f}}$ \\
\hline SC & $11 \pm 0.64$ & $980 \pm 125.53$ & $1.0 \pm 0.42$ & $9 / 10$ & $0 / 4$ \\
OT & $7 \pm 0.40$ & $2552 \pm 582.97$ & $1.8 \pm 0.52$ & $9 / 10$ & $4 / 4$ \\
\hline
\end{tabular}

${ }^{a} 10 \times 10^{6}$ viable tumour cells were injected into the pancreas or subcutis of two groups of 10 mice/group. ${ }^{b}$ Days post-injection ( \pm SE), when the tumours could be palpated. ${ }^{c}$ Tumour volume $\left(\mathrm{mm}^{3} \pm\right.$ s.e.) on day 20 Tumour size was measured with a caliper. ${ }^{\mathrm{d}}$ Average of the weight (in grams \pm s.e.) of the tumours isolated from different mice. ${ }^{e}$ Number of mice with tumours/number of injected mice. ${ }^{f}$ Lymph node (LN) metastases include mediastinal lymph node, mesenteric lymph node, iliac lymph node, and inguinal lymph node metastases. 
metastasised to LNs in all animals compared to no metastasis in the SC tumours.

\section{Expression of MUC4 mRNA by OT and SC tumours}

We further analysed the status of MUC4 transcripts in the tumours that are generated in two different host environments. Total RNA isolated from the tumour cell line (CD18/HPAF), tumour tissues, and normal human pancreas was fractionated on agarose gel electrophoresis, Northern blotted, and probed with a MUC4 tandem repeat cDNA probe. As reported in our previous study (Choudhury et al, 2000b), the MUC4 cDNA probe hybridised to a large-sized transcript $(\sim 26.5 \mathrm{~kb})$ in CD18/HPAF cells, and showed a smear ranging from 10 to $29 \mathrm{~kb}$ in the OT tumours on Northern blot (Figure 1). The conceptual expected transcript size of the MUC4 in HPAF cells will be $\sim 26.5 \mathrm{~kb}$ (Choudhury et al, 2000a). OT tumours showed an MUC4 transcript similar or little higher than the parental cell line CD18/HPAF (Figure 1). On the other hand, MUC4 was not detected in the SC tumour, and the value showed in Figure 1 is the background. The MUC4 mRNA expression in normal human pancreas was below the background level.

\section{Histology and MUC4 protein expression in tumours}

We studied the tumour histology of the MUC4-expressing OT as well as the tumours showing undetectable MUC4 expression, and
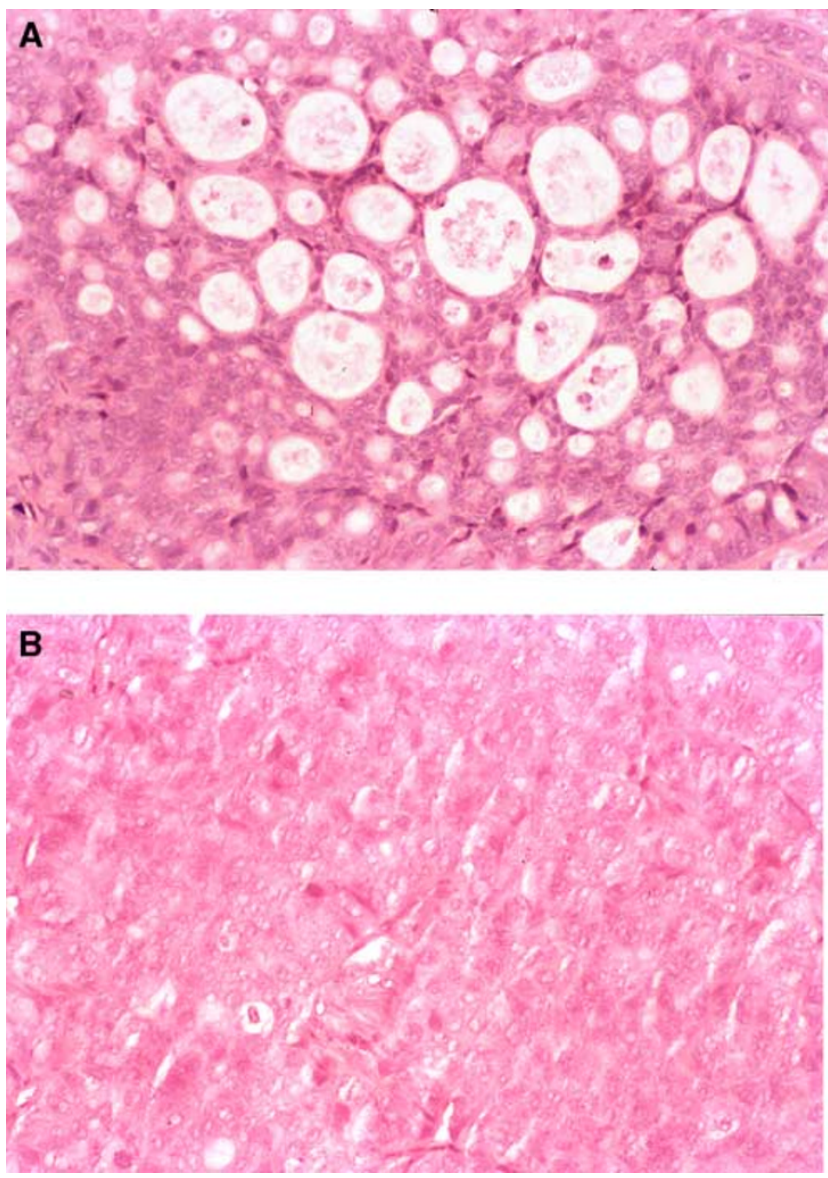

Figure 2 Tumour of CDI8/HPAF cells grown in nude mice. (A) OT tumour showing a moderately differentiated tumour with glandular structures filled with mucin. (B) The same cells grown in SC tissue, showing an amorphous mass of tumour cells with no signs of differentiation. Original $\times 32$ were interested to see if there is any correlation with the tumour morphology. Histopathological examination of the tumour tissues stained with haematoxylin and eosin revealed well-developed duct formation and cellular polarisation in the OT tumour (Figure 2A). In contrast, the SC tumour sections showed an amorphous mass of cells with very little development of ducts in the tumours, and the cells were anaplastic. The tumour cells lacked cellular polarisation and, therefore, did not form luminal spaces (Figure 2B).

The MUC4 protein expressions in OT and SC tumour sections were determined by IHC, using a rabbit polyclonal antiserum raised against MUC4 (Choudhury et al, 2000b). The immunoreactivity of the anti-MUC4 antibody was seen in OT tumour sections (Figure 3A), but not in SC tumour sections (Figure 3B). The positive staining in the OT tumour section was specifically blocked by pre-incubation of the MUC4-antiserum with the tandem repeat peptide (data not shown). The control sera (i.e., the pre-immune sera) did not show reactivity with any tumours. The OT tumours showed metastases to the LNs (Table 1). The metastasised LN tumours showed morphology and MUC4 staining similar to that observed in the OT tumours (data not shown).

\section{In vitro expression of MUC4 mRNA by OT and SC tumour cells}

To answer the question if there was a clonal expansion of nonMUC4-expressing cells in the SC tumours (showing undetectable
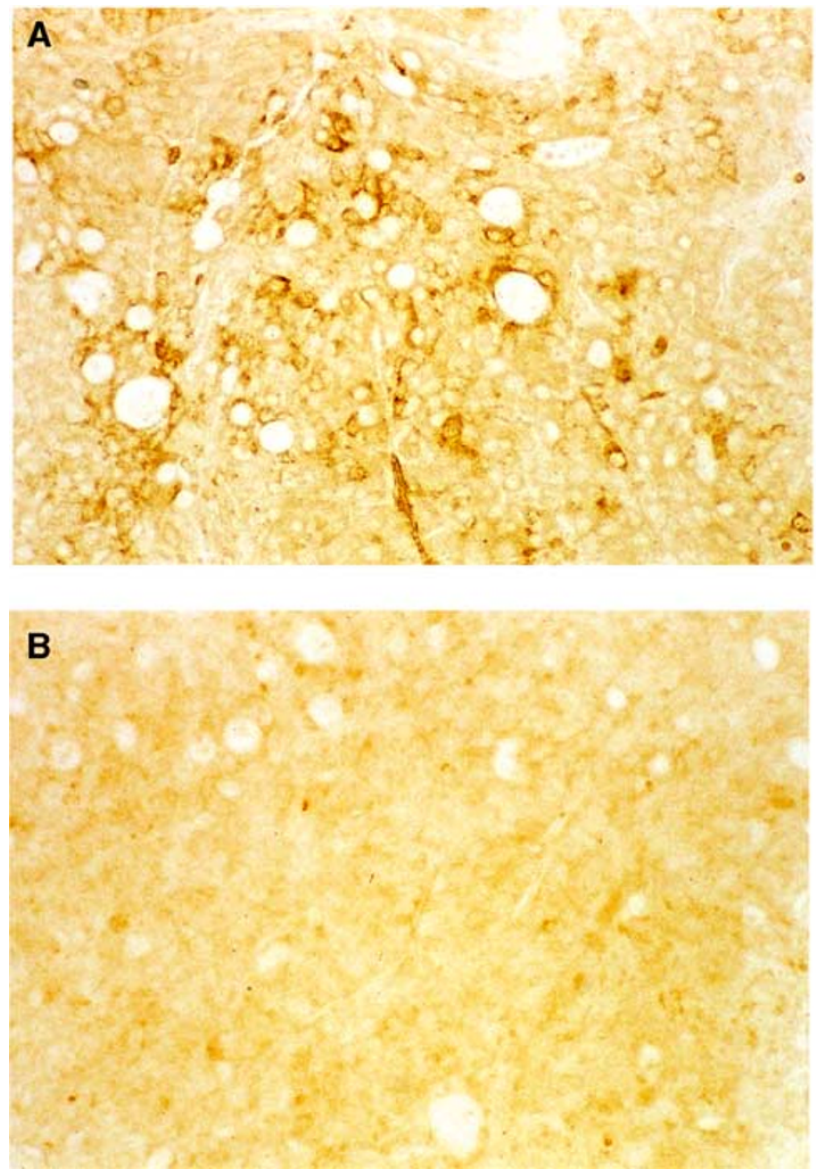

Figure 3 Immunohistochemical staining of CDI8/HPAF cells grown in the pancreas of the nude mouse $(\mathbf{A})$ and in SC tissues (B). The CDI8/ HPAF tumours in the pancreas show immunoreactivity to anti-MUC4 antiserum (I : I00 dilution (A)), whereas the pancreatic tissue of the nude mouse remains unstained, as do the tumours grown in SC tissue (B) Original $\times 50(\mathbf{A}, \mathbf{B})$ 
levels of MUC4), we isolated and cultured cells from the SC tumours, and studied the MUC4 expression. In SC tumour cells cultured in vitro, MUC4 mRNA expression appeared gradually and increased from passage 2 to 6 , with an expression level similar to MUC4 in the CD18/HPAF parental cell line in later passages (Figure 4). OT tumour cells in culture showed a transient decrease in the level of MUC4 transcripts and also exhibited a level comparable to MUC4 in CD18/HPAF (Figure 4) in the later passages.

\section{TGF $\beta$ expression in tumour cells, OT and SC tumours}

Previously, we demonstrated a positive correlation in the expression of MUC4 and TGF $\beta 2$ transcripts (Choudhury et al, $2000 \mathrm{~b})$. For this analysis, the expression of TGF $\beta 1$ and TGF $\beta 2$ was studied by RT-PCR using total RNA isolated from CD18/HPAF cells and OT and SC tumours (Figure 5). We found that OT tumours showed TGF 22 expression with a range two-fold higher than the parental cell lines CD18/HPAF. However, the SC tumour samples showed no undetectable TGF $\beta 2$ expression. Sometimes, a very low level of TGF $\beta 2$ was detected in SC tumours (two out of the six) without expression of MUC4 (data not shown). On the other hand, the expression of TGF $\beta 1$ was found to be similar in tumours (OT and SC) and the CD18/HPAF cells.

A
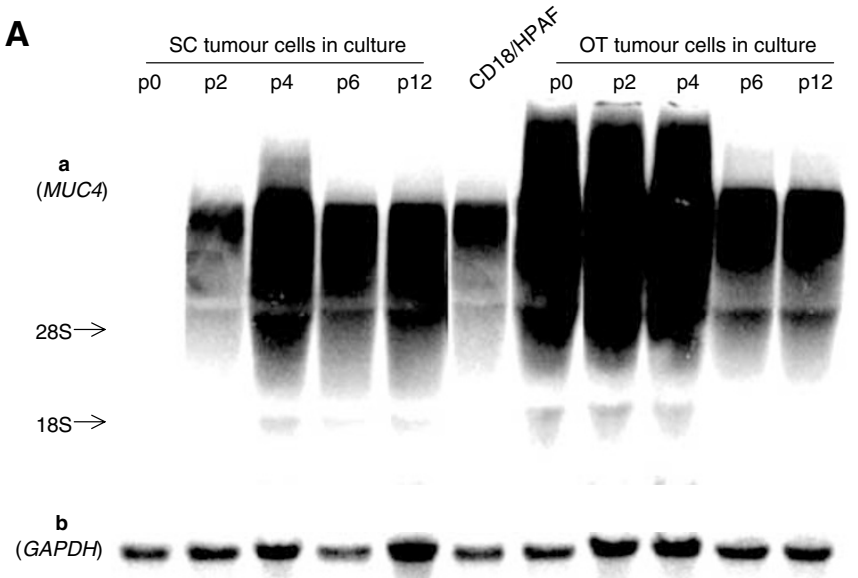

B

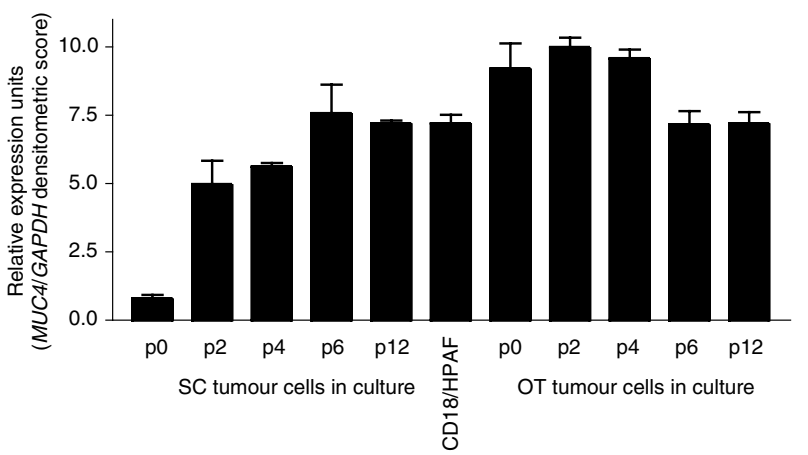

Figure 4 (A) Northern blot of total cellular RNA (20 $\mu \mathrm{g})$ extracted from SC tumour cells, OT tumour cells at different passages and CDI8/ HPAF cell line, separated in a $1 \%$ agarose/formaldehyde gel. (a) Probed with ${ }^{32}$ P-labelled MUC4 tandem repeat cDNA probe. (b) The same membrane as shown in (a), probed with a GAPDH cDNA probe. (B) Densitometric values $( \pm$ s.e.) for the bands in three different experiments were determined by using Molecular Dynamics ImageQuant software program. Values obtained for the MUC4 smear were divided by the densitometric values for the GAPDH band.
As a control, another cell line, SW1990, was used to validate the results. The SW1990 line was implanted in OT and SC sites in nude mice. Expression of MUC4 as well as TGF $\beta 2$ was investigated. The SW1990 OT exhibited a high level of MUC4 and TGF $\beta 2$, as compared to the SW1990 parental line or the SW1990 SC (data not shown).

\section{Expression of mucin genes in normal human pancreas, CD18/HPAF cell line, OT and SC tumours}

To obtain a comparative picture of MUC4 expression along with other mucin genes, RT-PCR amplification was performed using mucin gene-specific and GAPDH primers designed from the published sequences in the GenBank. A comparison of mucin gene expression in the normal human pancreas tissue, pancreatic tumour cell line (CD18/HPAF), and tumour tissues (OT and SC) is shown in Table 2. Consistent with the Northern blot and IHC, RT PCR showed no expression of MUC4 in the normal human pancreas and the SC tumours, whereas a high level of MUC4 expression was found in the CD18/HPAF cell line and the OT tumours. The expression of $M U C 1$ and $M U C 5 B$ appeared similar in all the samples. MUC2 was detected only in the tumour cell line, but not in the normal human pancreas and tumour samples. The expression of MUC5AC was weak in OT and SC tumours, with traces in the cell line and normal human pancreas. MUC6 was detected at a high level only in the normal pancreas. MUC3 and MUC7 mRNA expression was not detected in the CD18/HPAF cell line and tumour samples. The positive controls (as mentioned in the Materials and methods section) for MUC2, MUC3, MUC5AC, $M U C 5 B$, and $M U C 7$ showed mucin expression. Among eight mucin genes analysed, MUC4 was the only gene that showed high levels of expression in OT tumours, with no detectable expression in the normal pancreas or SC tumours. For PCR analysis, primers were designed in the non-tandem repeat regions of the human mucin genes. The amplified PCR products for each mucin gene showed the expected size with $100 \%$ sequence identity to the corresponding human sequences, thereby ruling out the possibility of amplification of the mouse Muc4.

\section{DISCUSSION}

The MUC4 mucin exhibits a pancreatic tumour-associated expression, with no detectable expression in a normal pancreas (Balague et al, 1994; Hollingsworth et al, 1994; Kim et al, 1999; Choudhury et al, 2000a; Andrianifahanana et al, 2001). Based upon the structural information, MUC4 has been proposed to exist as a heterodimeric molecule consisting of a large mucin-type subunit and a membrane-anchored subunit with three EGF-like domains (Moniaux et al, 1999; Choudhury et al, 2000a). It has been proposed that the MUC4 mucin may have growth factor-like properties, because its rat homologue (rat Muc4) is referred to interact with the oncogene p185 $185^{\text {neu }}$ (Carraway et al, 1999). Overexpression of SMC (rat Muc4) has been shown to promote tumour growth in primary tumours and has resulted in metastasis (Komatsu et al, 2000).

In the present study, the effect of the host local environment on MUC4 expression was examined in nude mice. The clonal human pancreatic cancer cell line CD18/HPAF that expresses a high level of MUC4 mRNA (Choudhury et al, 2000b) was used for generating human pancreatic xenografts at different sites in nude mice. We observed significantly higher tumour growth $(P<0.01)$ rates after implantation at OT sites compared to SC sites in nude mice. In addition, the OT tumours also showed a high incidence of metastasis to regional LNs, and distant metastasis to mediastinal LNs and mesenteric LNs. A high level of MUC4 transcripts and proteins was observed in the human pancreatic tumour xenografts at an OT site, a site analogous to human pancreas that does not 
show MUC4 expression, compared to SC sites. When tumours were generated at other MUC4-expressing sites in nude mice like SMG and stomach, these tumours also showed equivalent levels of MUC4 (unpublished result). Pancreas, SMG, and stomach, being physiologically active organs that are well perfused compared to the SC environment, have spare vasculature. The MUC4-expressing cells, when grown in the wellvascularised site (OT), revealed a high level of MUC4 expression,

A

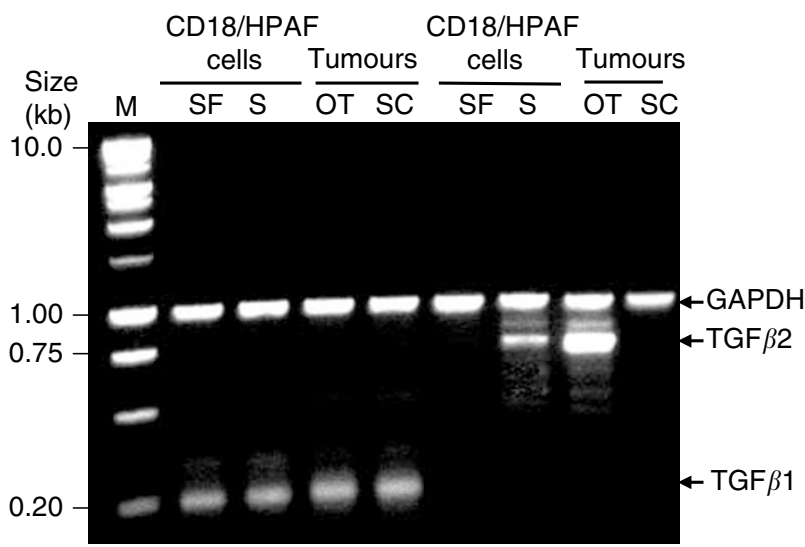

B

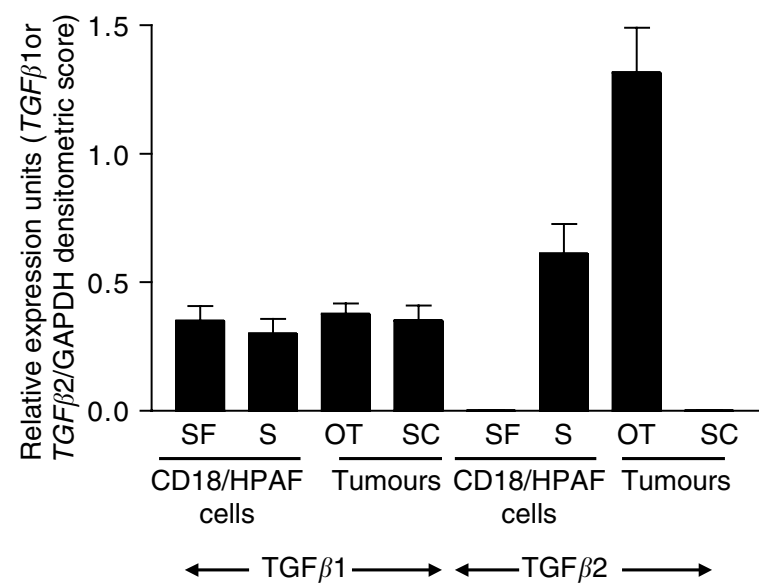

Figure 5 (A) Analysis of TGF $\beta 1$ and TGF $\beta 2$ expression in CDI8/HPAF cells, OT tumours, and SC tumours. Total RNA was isolated; TGF $\beta$ and GAPDH mRNA are coamplified in each reaction by RT-PCR. (B) The band intensity of the amplified products was quantified for each sample using the gel expert ${ }^{\mathrm{TM}} 3.5$ software suite. The densitometric values ( \pm s.e.) for the bands in three different experiments were calculated for a gene-specific product and GAPDH for each reaction. The value for a gene-specific product is expressed per unit of GAPDH to account for any differences in the starting amounts of RNA. OT, orthotopic tumour; SC, subcutaneous tumour; S, serum; SF, serum-free. as compared to a less-vascularised (SC) environment. The observation suggests a role of serum factors in regulating the MUC4 expression, or there may be a clonal expansion of a nonMUC4-expressing cell type in the SC tumours. To answer these questions, we harvested SC tumour cells and cultured them in vitro. The in vitro culture of SC tumour cells returned the expression of MUC4 transcripts to the parental cell line level, further suggesting a role of serum factor(s) in regulating MUC4 expression. Our earlier study also demonstrates a serum-dependent increase in MUC4 expression in human pancreatic tumour cells (Choudhury et al, 2000b).

Further, histological examination of the tumours revealed the OT tumours as moderately differentiated, whereas the SC tumours were poorly differentiated, suggesting that the expression of MUC4 could be influenced by the differentiation grade of tumours. We have made similar observations on a panel of pancreatic tumour cell lines, where a majority of differentiated adenocarcinomas showed higher levels of MUC4 transcripts compared to cell lines derived from poorly differentiated adenocarcinomas (Hollingsworth et al, 1994; Choudhury et al, 2000a; Andrianifahanana et al, 2001).

The lack of detectable expression of MUC4 in SC tumours could also be due to paracrine regulation from the surrounding tissue environment that may be blocking the transcription of MUC4. Paracrine stimulation by growth factors and cytokines has been demonstrated to be one of the mechanisms responsible for the organ preference and proliferation of the tumour cells. In the human colon carcinoma cell line, paracrine stimulation by a soluble factor from human colon connective tissue was involved in inducing the expression of the MUC1 mucin in vitro (Irimura et al, 1990). Cytokine-like tumour necrosis factor- $\alpha$, interleukins, and EGF have been shown to be involved in the regulation of mucin gene expression (Dabbagh et al, 1999; Longphre et al, 1999; Takeyama et al, 1999; Kim et al, 2000; Smirnova et al, 2000). One of the cytokines (i.e. TGF- $\beta$ ) showed an increased expression in many advanced human cancers (Gorsch et al, 1992; Gold et al, 1994) including pancreatic cancer (Friess et al, 1993a, b). A TGF $\beta 2$-dependent increase in MUC4 expression in pancreatic adenocarcinoma (Choudhury et al, 2000b) and elevated levels of TGF $\beta 2$ transcripts in MUC4-expressing OT tumours suggest the involvement of this cytokine in MUC4 regulation by autocrine and/or paracrine manner in CD18/HPAF tumours. Nevertheless, the expression of MUC4 is also regulated by TGF $\beta 2$, post-translationally and post-transcriptionally in normal and mammary adenocarcinoma cells, respectively (Price-Schiavi et al, 1998, 2000).

Earlier studies have shown that the organ environment can influence tumorigenesis; production of degradative enzymes; melanin and angiogenic molecules; induction of terminal differentiation; level of P-glycoprotein associated with the multiple drug-resistance phenotype; and IL-8 expression (Hart and Fidler, 1980; Price et al, 1988; Nakajima et al, 1990; Staroselsky et al, 1990; Fabra et al, 1992; Wilmanns et al, 1992; Radinsky et al, 1994; Gutman et al, 1995). The influence of the organ environment on the growth of tumour cells was originally proposed in Paget's hypothesis of the 'seed and the soil' (Paget, 1989).

Table 2 RT-PCR expression analysis of mucin genes expression

\begin{tabular}{|c|c|c|c|c|c|c|c|c|}
\hline Sample & MUCI & MUC2 & MUC3 & MUC4 & MUC5AC & MUC5B & MUC6 & MUC7 \\
\hline OT tumour & +++ & - & - & +++ & + & ++ & - & - \\
\hline Pancreas & ++ & - & - & - & $+1-$ & ++ & ++ & - \\
\hline
\end{tabular}

Three orthotopic (OT), three subcutaneous (SC), and seven normal human pancreas were analysed. +++, high; ++, moderate; +, low; -, undetectable; ND, not determined. 
In summary, we believe that this is the first study showing in vivo regulation of human MUC4 expression in pancreatic tumours. The expression of MUC4 was high in moderately differentiated tumours, with undetectable levels in poorly differentiated SC tumours. The OT tumours also showed metastases not only to the regional but also to the distant LNs. The SC tumour cells, when cultured in vitro, showed MUC4 expression, suggesting a role of serum factor(s) in its regulation. Our results also indicated a direct correlation between the MUC4 expression and the levels of TGF $\beta 2$ transcripts in the CD18/HPAF tumours, as well as in CD18/HPAF cells in vitro, as described earlier (Choudhury et al, 2000b). These results reveal that the local host environment regulates the MUC4 expression in pancreatic tumours (CD18/HPAF) under in vivo conditions.

\section{ACKNOWLEDGEMENTS}

The invaluable technical support of Mr Erik Moore was greatly appreciated. We would also like to thank the Molecular Biology Core Facility, UNMC, for oligonucleotide synthesis and DNA sequencing, and Ms Kristi LW Berger, editor, Eppley Institute, for editorial assistance.

\section{REFERENCES}

Andrianifahanana $M$, Moniaux N, Schmied BM, Ringel J, Friess $H$, Hollingsworth M, Buchler MW, Aubert JP, Batra SK (2001) Mucin (MUC) gene expression in human pancreatic adenocarcinoma and chronic pancreatitits: a potential role of MUC4 as a tumor marker of diagnostic significance. Clin Cancer Res 7: 4033-4040

Aubert JP, Porchet N, Crepin M, Duterque-Coquillaud M, Vergnes G, Mazzuca M, Debuire B, Petitprez D, Degand P (1991) Evidence for different human tracheobronchial mucin peptides deduced from nucleotide cDNA sequences. Am J Respir Cell Mol Biol 5: 178-185

Audie JP, Janin A, Porchet N, Copin MC, Gosselin B, Aubert JP (1993) Expression of human mucin genes in respiratory, digestive, and reproductive tracts ascertained by in situ hybridization. J Histochem Cytochem 41: 1479-1485

Balague C, Gambus G, Carrato C, Porchet N, Aubert JP, Kim YS, Real FX (1994) Altered expression of MUC2, MUC4, and MUC5 mucin genes in pancreas tissues and cancer cell lines. Gastroenterology 106: 1054-1061 Batra SK, Castelino-Prabhu S, Wikstrand CJ, Zhu X, Humphrey PA, Friedman HS, Bigner DD (1995) Epidermal growth factor ligandindependent, unregulated, cell-transforming potential of a naturally occurring human mutant EGFRvIII gene. Cell Growth Differ 6: $1251-1259$

Bobek LA, Tsai H, Biesbrock AR, Levine MJ (1993) Molecular cloning, sequence, and specificity of expression of the gene encoding the low molecular weight human salivary mucin (MUC7). J Biol Chem 268: 20563-20569

Buisine MP, Devisme L, Copin MC, Durand-Reville M, Gosselin B, Aubert JP, Porchet N (1999) Developmental mucin gene expression in the human respiratory tract. Am J Respir Cell Mol Biol 20: 209-218

Carraway KL, Rossi EA, Komatsu M, Price-Schiavi SA, Huang D, Guy PM, Carvajal ME, Fregien N, Carraway CA (1999) An intramembrane modulator of the ErbB2 receptor tyrosine kinase that potentiates neuregulin signaling. J Biol Chem 274: 5263-5266

Chirgwin JM, Przybyla AE, MacDonald RJ, Rutter WJ (1979) Isolation of biologically active ribonucleic acid from sources enriched in ribonuclease. Biochemistry 18: 5294-5299

Choudhury A, Moniaux N, Winpenny JP, Hollingsworth MA, Aubert JP, Batra SK (2000a) Human MUC4 mucin cDNA and its variants in pancreatic carcinoma. J Biochem 128: 233-243

Choudhury A, Singh RK, Moniaux N, El-Metwally TH, Aubert JP, Batra SK (2000b) Retinoic acid-dependent transforming growth factor-beta 2-mediated induction of MUC4 mucin expression in human pancreatic tumor cells follows retinoic acid receptor-alpha signaling pathway. J Biol Chem 275: 33929-33936

Dabbagh K, Takeyama K, Lee HM, Ueki IF, Lausier JA, Nadel JA (1999) IL-4 induces mucin gene expression and goblet cell metaplasia in vitro and in vivo. J Immunol 162: 6233-6237

Dufosse J, Porchet N, Audie JP, Guyonnet DV, Laine A, Van-Seuningen I, Marrakchi S, Degand P, Aubert JP (1993) Degenerate 87-base-pair tandem repeats create hydrophilic/hydrophobic alternating domains in human mucin peptides mapped to 11p15. Biochem J 293: 329-337

Fabra A, Nakajima M, Bucana CD, Fidler IJ (1992) Modulation of the invasive phenotype of human colon carcinoma cells by organ specific fibroblasts of nude mice. Differentiation 52: 101-110

Fidler IJ, Wilmanns C, Staroselsky A, Radinsky R, Dong Z, Fan D (1994) Modulation of tumor cell response to chemotherapy by the organ environment. Cancer Metastasis Rev 13: 209-222
Friess H, Yamanaka Y, Buchler M, Berger HG, Kobrin MS, Baldwin RL, Korc M (1993a) Enhanced expression of the type II transforming growth factor beta receptor in human pancreatic cancer cells without alteration of type III receptor expression. Cancer Res 53: 2704-2707

Friess H, Yamanaka Y, Buchler M, Ebert M, Beger HG, Gold LI, Korc M (1993b) Enhanced expression of transforming growth factor beta isoforms in pancreatic cancer correlates with decreased survival. Gastroenterology 105: $1846-1856$

Gendler SJ, Lancaster CA, Taylor-Papadimitriou J, Duhig T, Peat N, Burchell J, Pemberton L, Lalani EN, Wilson D (1990) Molecular cloning and expression of human tumor-associated polymorphic epithelial mucin. J Biol Chem 265: 15286-15293

Gendler SJ, Spicer AP (1995) Epithelial mucin genes. Annu Rev Physiol 57: 607-634

Gipson IK, Spurr-Michaud S, Moccia R, Zhan Q, Toribara N, Ho SB, Gargiulo AR, Hill JA (1999) MUC4 and MUC5B transcripts are the prevalent mucin messenger ribonucleic acids of the human endocervix. Biol Reprod 60: $58-64$

Gold LI, Saxena B, Mittal KR, Marmor M, Goswami S, Nactigal L, Korc M, Demopoulos RI (1994) Increased expression of transforming growth factor beta isoforms and basic fibroblast growth factor in complex hyperplasia and adenocarcinoma of the endometrium: evidence for paracrine and autocrine action. Cancer Res 54: 2347-2358

Gorsch SM, Memoli VA, Stukel TA, Gold LI, Arrick BA (1992) Immunohistochemical staining for transforming growth factor beta 1 associates with disease progression in human breast cancer. Cancer Res 52: $6949-6952$

Gum JR Jr, Hicks JW, Toribara NW, Siddiki B, Kim YS (1994) Molecular cloning of human intestinal mucin (MUC2) cDNA. Identification of the amino terminus and overall sequence similarity to prepro-von Willebrand factor. I Biol Chem 269: 2440-2446

Gum JR Jr, Ho JJ, Pratt WS, Hicks JW, Hill AS, Vinall LE, Roberton AM, Swallow DM, Kim YS (1997) MUC3 human intestinal mucin. Analysis of gene structure, the carboxyl terminus, and a novel upstream repetitive region. J Biol Chem 272: 26678-26686

Gum JR Jr, Crawley SC, Hicks JW, Szymkowski DE, Kim YS (2002) MUC17, a novel membrane-tethered mucin. Biochem Biophys Res Commun 291: $466-475$

Gutman M, Singh RK, Xie K, Bucana CD, Fidler IJ (1995) Regulation of interleukin-8 expression in human melanoma cells by the organ environment. Cancer Res 55: 2470-2475

Hart IR, Fidler IJ (1980) Role of organ selectivity in the determination of metastatic patterns of B16 melanoma. Cancer Res 40: 2281-2287

Hollingsworth MA, Strawhecker JM, Caffrey TC, Mack DR (1994) Expression of MUC1, MUC2, MUC3 and MUC4 mucin mRNAs in human pancreatic and intestinal tumor cell lines. Int J Cancer 57: 198-203

Irimura T, Mcisaac AM, Carlson DA, Yagita M, Grimm EA, Menter DG, Ota DM, Clary KR (1990) Soluble factor in normal tissues that stimulates high-molecular-weight sialoglycoprotein production by human colon carcinoma cells. Cancer Res 50: 3331-3338

Kim YD, Kwon EJ, Kwon TK, Baek SH, Song SY, Suh JS (2000) Regulation of IL-1beta-mediated MUC2 gene in NCI-H292 human airway epithelial cells. Biochem Biophys Res Commun 274: 112-116

Kim YS, Gum JR, Crawley SC, Deng G, Ho JJ (1999) Mucin gene and antigen expression in biliopancreatic carcinogenesis. Ann Oncol 10(Suppl 4): $51-55$ 
Kim YW, Kern HF, Mullins TD, Koriwchak MJ, Metzgar RS (1989) Characterization of clones of a human pancreatic adenocarcinoma cell line representing different stages of differentiation. Pancreas 4: 353-362

Komatsu M, Carraway CA, Fregien NL, Carraway KL (1997) Reversible disruption of cell-matrix and cell-cell interactions by overexpression of sialomucin complex. J Biol Chem 272: 33245 - 33254

Komatsu M, Tatum L, Altman NH, Carothers CC, Carraway KL (2000) Potentiation of metastasis by cell surface sialomucin complex (rat MUC4), a multifunctional anti-adhesive glycoprotein. Int J Cancer 87: $480-486$

Kyriazis AP, McCombs WB, Sandberg AA, Kyriazis AA, Sloane NH, Lepera $\mathrm{R}$ (1983) Establishment and characterization of human pancreatic adenocarcinoma cell line SW-1990 in tissue culture and the nude mouse. Cancer Res 43: $4393-4401$

Lan MS, Batra SK, Qi WN, Metzgar RS, Hollingsworth MA (1990) Cloning and sequencing of a human pancreatic tumor mucin cDNA. J Biol Chem 265: $15294-15299$

Longphre M, Li D, Gallup M, Drori E, Ordonez CL, Redman T, Wenzel S, Bice DE, Fahy JV, Basbaum C (1999) Allergen-induced IL-9 directly stimulates mucin transcription in respiratory epithelial cells. J Clin Invest 104: $1375-1382$

Marincola FM, Drucker BJ, Siao DY, Hough KL, Holder WDJ (1989) The nude mouse as a model for the study of human pancreatic cancer. J Surg Res 47: $520-529$

Metzgar RS, Gaillard MT, Levine SJ, Tuck FL, Bossen EH, Borowitz MJ (1982) Antigens of human pancreatic adenocarcinoma cells defined by murine monoclonal antibodies. Cancer Res 42: 601-608

Moniaux N, Escande F, Porchet N, Aubert JP, Batra SK (2001) Structural organization and classification of the human mucin genes. Front Biosci 6: $1192-1206$

Moniaux N, Nollet S, Porchet N, Degand P, Laine A, Aubert JP (1999) Complete sequence of the human mucin MUC4: a putative cell membrane-associated mucin. Biochem J 338: 325-333

Nakajima M, Morikawa K, Fabra A, Bucana CD, Fidler IJ (1990) Influence of organ environment on extracellular matrix degradative activity and metastasis of human colon carcinoma cells. J Natl Cancer Inst 82: $1890-1898$

Nollet S, Moniaux N, Maury J, Petitprez D, Degand P, Laine A, Porchet N, Aubert JP (1998) Human mucin gene MUC4: organization of its 5'-region and polymorphism of its central tandem repeat array. Biochem $J$ 332: $739-748$

Paget S (1989) The distribution of secondary growths in cancer of the breast. 1889. Cancer Metastasis Rev 8: 98-101

Porchet N, Nguyen VC, Dufosse J, Audie JP, Guyonnet-Duperat V, Gross MS, Denis C, Degand P, Bernheim A, Aubert JP (1991) Molecular cloning and chromosomal localization of a novel human tracheo-bronchial mucin cDNA containing tandemly repeated sequences of 48 base pairs. Biochem Biophys Res Commun 175: 414-422

Pour PM, Kazakoff K, Dulaney K (1993) A new multilabeling technique for simultaneous demonstration of different islet cells in permanent slides. Int J Pancreatol 13: $139-142$

Price JE, Tarin D, Fidler IJ (1988) Influence of organ microenvironment on pigmentation of a metastatic murine melanoma. Cancer Res 48: $2258-2264$
Price-Schiavi SA, Carraway CA, Fregien N, Carraway KL (1998) Posttranscriptional regulation of a milk membrane protein, the sialomucin complex (Ascites sialoglycoprotein (ASGP)-1/ASGP-2, rat muc4), by transforming growth factor beta. J Biol Chem 273: $35228-35237$

Price-Schiavi SA, Zhu X, Aquinin R, Carraway KL (2000) Sialomucin complex (rat Muc4) is regulated by transforming growth factor beta in mammary gland by a novel post-translational mechanism. J Biol Chem 275: $17800-17807$

Radinsky R, Fidler IJ, Price JE, Esumi N, Tsan R, Petty CM, Bucana CD, Bar-Eli M (1994) Terminal differentiation and apoptosis in experimental lung metastases of human osteogenic sarcoma cells by wild type p53. Oncogene 9: 1877-1883

Reid CJ, Harris A (1998) Developmental expression of mucin genes in the human gastrointestinal system. Gut 42: 220-226

Shankar V, Pichan P, Eddy RLJ, Tonk V, Nowak N, Sait SN, Shows TB, Schultz RE, Gotway G, Elkins RC, Gilmore MS, Sachdev GP (1997) Chromosomal localization of a human mucin gene (MUC8) and cloning of the cDNA corresponding to the carboxy terminus. Am J Respir Cell Mol Biol 16: $232-241$

Smirnova MG, Birchall JP, Pearson JP (2000) TNF-alpha in the regulation of MUC5AC secretion: some aspects of cytokine-induced mucin hypersecretion on the in vitro model. Cytokine 12: 1732-1736

Staroselsky AN, Fan D, O’Brian CA, Bucana CD, Gupta KP, Fidler IJ (1990) Site-dependent differences in response of the UV-2237 murine fibrosarcoma to systemic therapy with adriamycin. Cancer Res 50: $7775-7780$

Swart MJ, Batra SK, Varshney GC, Hollingsworth MA, Yeo CJ, Cameron JL, Wilentz RE, Hruban RH, Argani P (2002) MUC4 expression increases progressively in pancreatic intraepithelial neoplasia (PanIN). Am J Clin Pathol 117: 791 -796

Takeyama K, Dabbagh K, Lee HM, Agusti C, Lausier JA, Ueki IF, Grattan KM, Nadel JA (1999) Epidermal growth factor system regulates mucin production in airways. Proc Natl Acad Sci USA 96: 3081-3086

Toribara NW, Ho SB, Gum E, Gum JR Jr, Lau P, Kim YS (1997) The carboxyl-terminal sequence of the human secretory mucin, MUC6. Analysis of the primary amino acid sequence. J Biol Chem 272: 16398-16403

Vandenhaute B, Buisine MP, Debailleul V, Clement B, Moniaux N, Dieu MC, Degand P, Porchet N, Aubert JP (1997) Mucin gene expression in biliary epithelial cells. J Hepatol 27: 1057-1066

Williams SJ, McGuckin MA, Gotley DC, Eyre HJ, Sutherland GR, Antalis TM (1999) Two novel mucin genes down-regulated in colorectal cancer identified by differential display. Cancer Res 59: 4083- 4089

Williams SJ, Wreschner DH, Tran M, Eyre HJ, Sutherland GR, McGuckin MA (2001) MUC13, a novel human cell surface mucin expressed by epithelial and hemopoietic cells. J Biol Chem 276: $18327-18336$

Wilmanns C, Fan D, O’Brian CA, Bucana CD, Fidler IJ (1992) Orthotopic and ectopic organ environments differentially influence the sensitivity of murine colon carcinoma cells to doxorubicin and 5-fluorouracil. Int J Cancer 52: 98 - 104

Yin BW, Lloyd KO (2001) Molecular cloning of the CA125 ovarian cancer antigen: identification as a new mucin, MUC16. J Biol Chem 276: $27371-27375$ 